same time for controlling their emissions.

"It's very important for the two countries to put numbers on the table," says Jim Watson, a policy researcher at the University of Sussex in Brighton, UK.

In recent weeks other developing countries have made ambitious pledges. South Korea has promised a $30 \%$ cut below a business-as-usual scenario, and Brazil at least a $36 \%$ cut by 2020 . Both would be modest cuts compared with 2005 emissions.

India followed China's announcement by saying it would "be willing to sign on to an ambitious global target for emissions reductions or limiting temperature increase" - but with the catch that "this must be accompanied by an equitable burden-sharing paradigm". China and India, along with Brazil, South Africa and Sudan, last weekend reiterated developing countries' insistence that developed nations help bear the cost of climate change, including facilitating technology transfer (see page 555).

So far, the European Union has pledged the most aggressive emissions cuts in the developed world, of 20\% from 1990 levels by 2020 , to be increased to $30 \%$ below if rich non-EU nations follow suit. The US target announced last week would be equivalent to a 3\% reduction from 1990 levels.

Obama must also work with the Democrat-dominated Congress to pass climate legislation that would make its targets binding. The $17 \%$ cut he announced last week is in agreement with a bill passed by the House of Representatives earlier this year. The Senate is expected to vote on its own version of climate legislation early in 2010. The Environmental Protection Agency has the authority to regulate carbon dioxide emissions if Congress does not act.

Meanwhile, the Australian parliament has been trying to pass a climate ruling that would cut emissions by up to $25 \%$ from 2000 levels by 2020 . But on 1 December, the main opposition party elected a new leader who has vowed to oppose the bill, throwing its future into jeopardy. Australia has the highest emissions per capita of any developed nation.

China, if it sticks to its plans, may end up leading the way for developing countries. Compared with current levels, the new target would avoid 1 gigatonne of carbon dioxide emissions - equivalent to a quarter of what the world would need to do to limit global temperature rise to $2^{\circ} \mathrm{C}$ over pre-industrial times. "China would champion the fight against global warming," says Birol.

Jane Qiu

For more, see News, page 555, and www.nature.com/roadtocopenhagen.

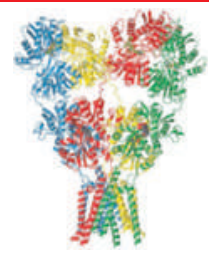

'TEMPLE OF THE MIND' UNLOCKED

Glutamate receptor mapped in detail go.nature.com/xUG9va

\title{
Battle lines drawn over e-mail leak
}

As the blogosphere continues to buzz with discussion about e-mails leaked from the Climatic Research Unit (CRU) at the University of East Anglia (UEA) in Norwich, UK, climatologists are insisting that the controversy will not discredit their science, or hamper a global climate deal.

CRU confirmed on 20 November that more than 1,000 e-mails and documents had been copied from its servers and distributed on the Internet (see Nature 462, 397; 2009). Since then, climate sceptics have seized on the material, citing the contents of selected e-mails as evidence that the case for anthropogenic global warming has been over-stated, and US Senator James Inhofe (Republican, Oklahoma) has promised an investigation into the affair.

Yet climate experts say the broader impact of the leak will be minimal. "Any suggestions that these e-mails will affect public and policy-makers' understanding of climate science give far too much credence to blog chatter and boastful spin," says Peter Frumhoff, director of science and policy at the Union of Concerned Scientists in Cambridge, Massachusetts.

Some, however, are pointing out that certain e-mails highlight a tendency for scientists to respond to critics either by retreating into an ivory tower, or by attempting to quiet dissenting voices. In an open letter posted on climateaudit.org, Judith Curry, a climatologist at Georgia Institute of Technology, Atlanta, wrote last week: "Scientists need to consider carefully skeptical arguments and either rebut them or learn from them. Trying to suppress them or discredit the skeptical researcher or blogger is not an ethical strategy and one that will backfire in the long run."

The UEA has launched an independent inquiry into both the security breach and whether CRU has dealt appropriately with the deluge of requests for raw climate data it has received under the UK Freedom of Information Act (see Nature 460, 787; 2009). It has also pointed out that more than 95\% of the raw data used in CRU climate models has been publicly available for several years.

\section{Quirin Schiermeier}

See Editorial, page 545.

\section{What the climate experts say}

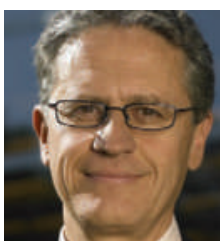

Thomas Stocker, University of Berne

"Science and science institutions should be transparent, but they are not a 24-hour help service for climate sceptics who lack fundamental scientific and technical skills."

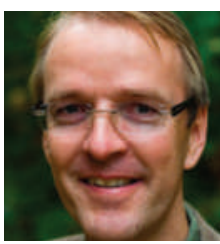

Svend Soeyland, of environment group Bellona Foundation, Washington DC

"Only openness will make the buzz go away. If only the vaguest impression lingers on that studies have been cooked up or that facts have been hidden it will feed conspiracy theories for ages."

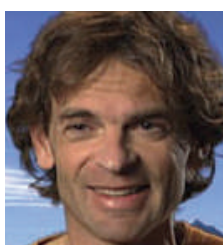

Eric Rignot, University of California, Irvine

"Given the overwhelming scientific evidence for climate change, we should deal less and less with climate sceptics. Otherwise we should also deal with folks who think Elvis Presley is still alive, that Earth is less than 6,000 years old and that we cannot possibly have descended from monkeys."

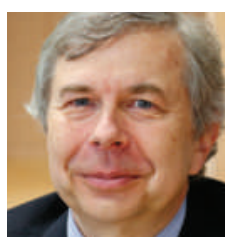

Guy Brasseur, National Center for Atmospheric Research in Boulder, Colorado

"It is important that scientists make their studies completely transparent, but the least ethical way to accuse others is to highlight a sentence and ignore the context in which this sentence has been written.”

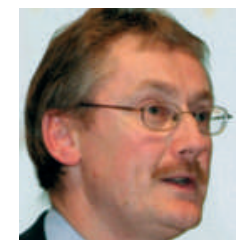

Mike Hulme, University of East Anglia, UK

"It is possible that climate science has become too partisan, too centralized. The tribalism that some of the leaked e-mails display is something more usually associated with social organization within pre-modern cultures; it is not attractive when we find it at work inside science."

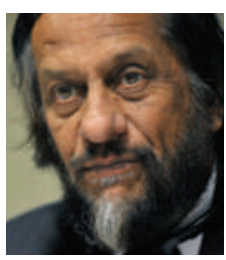

Rajendra Pachauri, chair of the Intergovernmental Panel on Climate Change

"I doubt that negotiations in Copenhagen will be influenced by this unfortunate incident." 